\title{
Audit expectation gap: an empirical analysis
}

\author{
Paul Olojede ${ }^{1 *}$, Olayinka Erin ${ }^{1}$, Osariemen Asiriuwa ${ }^{1}$ and Momoh Usman ${ }^{2}$
}

\begin{abstract}
The financial debacles that occurred in the companies like Enron, WorldCom, and Xerox in the USA, Lehman Brothers, Polly Peck in the UK and African Petroleum Plc., Cadbury Plc., in Nigeria had created public distrust with the auditors. The era when the auditor will say 'trust me' and that being accepted is over. Now, they must earn the public trust. This study provides an empirical analysis of the scope and nature of audit expectation gap in Nigeria. We used a descriptive and survey research design to achieve the objective of the study. We also collected data through primary source, using structured questionnaire. The study used Mann-Whitney $U$ test and Kolmogorov-Smirnov $Z$ test for the analysis of data and test of normality of distribution, respectively. The results confirmed that audit expectation gap exists in Nigeria, and the new auditor's report did not have any serious impact in reducing the gap. From the outcome of this study, the audit expectation gap primarily arose from the unreasonable expectation of the users due to their lack of understanding of the roles of auditors. We recommend the launching of a new business-reporting model geared towards releasing more non-financial information to the public and with clear description of the role of independent audit.
\end{abstract}

Keywords: Audit expectation gap, Audit failure, Corporate failure, New auditors report, Role conflict theory

\section{Introduction}

Auditing adds credibility to the financial statements and contributes tremendously to the efficient running of business organizations, the capital markets, and the economy as a whole [56]. However, the work of the auditors has become onerous because of globalization and its attendant risks of doing business, dynamic business environment, and increased sophistication in information technology. Based on the unprecedented opportunities, companies have expanded with more transactions that are complex, and control systems have become more sophisticated and highly computerized with technology such as advanced manufacturing technology used in running the factories. Although audit strategies have changed over the years, the changes have not matched with the dynamics in the business environment. Audit processes carry greater risk because of the use of statistical sampling techniques for audit tests. In addition, most of the computer-assisted audit techniques (CAATs)

\footnotetext{
*Correspondence: polojede@yahoo.co.uk

${ }^{1}$ Covenant University, Ota, Nigeria

Full list of author information is available at the end of the article
}

have their limitations. Most times, they fail to work with real-time data streams of today's business environment. Hence, they are not able to detect doubtful transactions such as potential frauds or irregularities.

The financial scandals of the recent years in the big companies like, Enron, Tyco, WorldCom, and in Nigeria, African Petroleum Plc. and Cadbury Nig. Plc exacerbate the above problems. These events have made the public who are at the receiving end to believe that the auditors either fail in their role or wilfully collude with the management and board. The stakeholders agitated because these corporate failures in many respects are traceable to the financial improprieties of the directors and yet, the auditors did not qualify their reports. For example, the distress witnessed in the banking sector in Nigeria between 1997 and 1999 was due to poor corporate governance and opportunistic behaviours of the directors. In addition, the banking industry experienced another failure in 2009 following the global credit crunch and the shock prompted the collapse of the capital market. Between 2002 and 2005, Cadbury Nig. Plc. overstated its profit by N13.25 billion and Akintola Williams Deloitte, the external auditors, failed to discover it. Similarly, in 
2007, the account of Nampak Nig. Plc. was equally overstated its by N2.8 billion, while the Board of defunct African Petroleum Plc. concealed N22.00 billion loan in its year 2000 accounts [47]. These are just few of the fraud cases in the private sector and in the public sector, it is even worse. Consequently, the profession has lost the confidence of the public and the greatest challenge is how to win back the public trust.

The question that has been agitating the minds of many stakeholders is: why are the auditors not held liable for the corporate failures, particularly when the accounts of these companies received clean bills. Maccarrone [39] believed that the astronomic rise in public agitation and controversies against the auditors was because of the financial scandals and audit failures of recent years. There is also a common belief by the various stakeholders that the audited accounts serve as certification of the company's solvency, propriety, and business viability [24]. Therefore, the public considers corporate failures in the firms to be synonymous with audit failures. When the audit process fails to detect fraud, there is always public outcry against the auditor and his work. Owolabi [53] seemed to align with this position by expressing that several billions of naira was lost by investors through the connivance of preparers of the accounts and auditors in falsifying the figures and hence, manipulating the earnings to reflect a position that is different from the true position. This is the basis for the conflict of interest between the users and auditors.

In the opinion of the users, the auditor's duties should be both explicit and implicit. That is, it should go beyond the statutory role. In fact, the perception of the users is that, an auditor through his professional capability could prevent and detect fraud, errors, and irregularities that might harm the users of accounts, whereas auditors in their opinion believe that they have an explicit role clearly defined by the law, such as Nigerian Companies and Allied Matters Act (CAMA) [15]. Akinbuli [5] argued that an auditor does not have the responsibility to detect fraud or irregularities. According to him, the primary responsibility of an auditor is to give credibility to the accounts prepared by the directors and in so doing, he exercises due care and skill in the conduct of his work.

The major area of conflict is the gap between the auditors' statutory role and public expectation of what is believed to be auditors' function. Sikka et al. [65] stated that the expectation gap of audit is paramount in the conduct of audit work because any unfulfilled expectations to the society would definitely lower the credibility and earning capability of the audit firm and by extension could be injurious to the stakeholders. The public trust is the 'heartbeat of any profession.' When the trust is lost, the result is credibility problem and erosion of value attached to the profession [11]. The indictment of Arthur Anderson in Enron's case showed the extent to which the judiciary could go in the interpretation of what constitutes the auditor's negligence and it is a wake-up call on the accountancy profession as a whole. For audit to sustain its relevance, the profession must improve on the speed of response to the demands of the society.

In view of the above challenges, the researcher is motivated to examine empirically the extent and nature of audit expectation gap in Nigeria, particularly with the introduction of new auditor's report in 2016. Although there exist vast documented studies on audit expectation gap in developed economies, most of the conclusions could not be adapted by the developing economies because of the cultural and legislative differences. Moreover, audit environment influences the views of the respondents. In Nigeria, not many studies documented the problem associated with expectation gap in audit and some researched works relatively used few sample size, while others restrict the sampled respondents to only a section of the population. Most importantly, many of the available studies in the country were conducted before 2016, when the new auditor's report had not been introduced. This study, therefore, attempts to add to knowledge by filling these gaps in the literature.

\section{Literature review}

\section{Auditing and accounting}

There are various ways to define accounting. Hence, the American Accounting Association's (AAA) definition was adopted in this study. This is because it is widely accepted in accounting literature. The AAA defines accounting as "the process of identifying, measuring and communicating economic and financial information to permit informed judgement and decision by the users of the information" (cited by Glautier and Underdown [23]; Olojede [47]). There is general acceptability that information derived from the financial statements is used for making economic decisions [70]. Thus, accounting information should be able to assist the users in his desire to "predict, compare and evaluate" his decision options [16,34]. The relevance, reliability, and comparability of information generated from financial statements become effective when it truly represents the 'economic substance' of an entity $[67,73]$.

Accounting information constitutes a major part of the total corporate information. Due to control and conflict of interest that arise between the principal and the agent, an independent person is engaged to verify the report of the agent to give credence to it due to the separation of ownership. The credibility that is added by auditing strengthens the quality of information in the financial statements. Flint [21] observed that auditing came 
into existence because interested individuals or groups were not able to obtain information or assurance needed on their own. He described audit function as a social control mechanism used to monitor conduct, evaluate performance, and enforce accountability. This is the whole essence of agency theory. Mautz and Sharaf [42] expressed the primary objective of audit is to examine the measurement and communication in property accounting. They further postulated that, "accounting information must be reliable. Otherwise, the existence of auditing is of no value" [47].

Auditing is an independent examination of the books and accounts with a view to reporting on the fairness of the financial statements. An auditor expresses opinion on truth and fairness of the financial statements prepared by the directors [18]. The American Accounting Association (AAA) through the Committee on Basic Auditing Concepts provided a definition, which is more acceptable. The committee's definition as cited by Arens et al. [10] expounded auditing as "a systematic process of objectively obtaining and evaluating evidence regarding assertion about economic actions and events to ascertain the degree of correspondence between those assertions and established criteria and communicating the results to interested users". This implies that an auditor must demonstrate professional prowess. He must be methodical, objective, and analytical in the conduct of his work, and be able to communicate effectively the results of his work to the stakeholders.

The agency theory, accounting theory, and auditing theory are intertwined. Although auditing and accounting are different phenomena, the two are, however, complementary. While accounting is concerned with the preparation and presentation of financial reports, auditing on the other hand entails an independent examination of accounts in order to give it credibility. Where an auditor accepts the responsibility for preparing accounts he only acts in that capacity as an accountant and not, as an auditor. This is why, it is important to state expressly the scope and nature of work in the letter of engagement [74]. Otherwise, the conflicting roles could undermine the independence of the auditor.

\section{Audit expectation gap}

The agency problem led to the services of auditors. The shareholders expect the auditors to give credence to the financial statement presented to them. Despite the importance of audit function, to define the role of auditors in the most acceptable way has always been a difficult task [8]. This challenge creates a perception gap between the users and auditors. The perception gap appears to have been exacerbated by the financial scandals of big companies like Enron and WorldCom. Liggio
[38] introduced the phrase "audit expectation gap". In his paper, he described the audit expectation gap as the difference in the perception of the users and auditors regarding the level of performance exhibited by the auditors in the course of their work. The Cohen Commission [14] expanded this definition to cover the gap that may exist between what the public expects and what the auditors can reasonably achieve. Porter [54] noticed that the definitions of Liggio [38] and Cohen Commission [14] failed to acknowledge that there could be sub-standard performance by the auditors. She attributed the recent increase in criticism of and litigation against auditors to the inability of the auditors to keep pace with the public demands (also cited by Akinbuli [5]). She defined audit expectation gap as the gap between the society's expectations of the auditors and the performance of the auditors.

Salehi [60] stated that "the audit expectation gap refers to either or both of these two: (1) differences in opinion on actual performance and expected performance of auditors (2) existence of these opinion differences between the auditors and users of accounts independently and comparatively". Public expectation can be described as a burglar alarm system, a radar system, a safety net, independent auditor, and coherent communication, which contradicts basic tenants of audit [72]. Lee et al. [35] in their study concluded that the users and the auditors perceive the nature and objectives of auditing differently. According to them, it is the conflict in by the two groups that is called "audit expectation gap". Ojo [45] defined audit expectation gap as "the difference between what the users of financial statements perceive an audit to be and what the audit profession claim is expected of them in conducting an audit". Within the context of regulation, audit expectation gap is defined as "an outcome of the contradiction of minimum government regulations and the profession's self-regulation, particularly the over-protection of self-interest, which has widened the expectation gap" [62]. Onulaka [51] suggested that audit expectation gap is the difference between what the public and users of financial statements believe the responsibilities of auditors should be and what the auditors believe their responsibilities are.

The confidence that the society places in the effectiveness of the audit work and the opinion of the auditor are the pivots on which audit function rests. When there is betrayal of confidence, the efficacy of the audit function is undermined $[19,55]$.

\section{Components of audit expectation gap}

The Canadian Institute of Chartered Accountants [40] sponsored a study on audit expectation gap, and the outcome (MacDonald Report) of the study conceptualized a model, which divided audit expectation gap into 
unreasonable expectation, deficient performance, and deficient standards. Building on this model, Porter [54] classified the expectation gap into two components to assist in reducing the audit expectations gap by treating each case on its own merit. Following her survey in New Zealand, she re-named the audit expectation gap as the "audit expectation-performance gap" and structured it into 'reasonable gap' and 'performance gap'. The reasonable gap described the difference between "what the public expects auditors to achieve and what they can reasonably be expected to accomplish". On the other hand, performance gap is the difference between "what the public can reasonably expect auditors to accomplish and what auditors are perceived to achieve". She further divided performance gap into 'deficient standard' and 'deficient performance.' Deficient standard is the gap between "what can reasonably be expected of auditors and auditors' existing duties as defined by the law and profession standards". Deficient performance is the difference between "the expected standard of performance of auditors' existing duties and auditors' perceived performance, as expected and perceived by the public".

The concept of audit materiality as a component of audit expectation gap has little attention in accounting literature $[4,27,43]$. However, it can be examined from two perspectives: the first relates to individual items in the financial statements, and the second relates to the financial statements as a whole [27]. Boterenbrod [13] studied audit expectation gap between companies and their auditors, using materiality of the financial statements as a whole for measurement. The results of his work showed that the materiality-level assumption by the preparers of the accounts was lower than what the auditors applied. However, many expectation gaps, which give rise to different structures and components, do exist in the literature [30, 46]. Hence, ACCA [1] proposed that the audit expectation be divided into three components and went into proposing different solutions into reducing them. The new components are knowledge gap, performance gap, and evolution gap. The knowledge gap is the difference between what the public thinks auditors do and what the auditors actually do. This takes into cognizance the fact that the public can misunderstand auditors work. The performance gap concentrates on where auditors fail to comply with the regulations or standards. The evolution gap focuses on the areas of audit where there is need for evolution based on the general public demand, technological changes and where the overall audit process can be improved through value addition.

\section{Causes of audit expectation gap}

The audit expectation gap, which has become a threat to the auditing profession, is attributed to many factors.
Tricker [71] observed that audit expectation gap is caused by the time lag in the auditing profession in identifying and responding to continually evolving and expanding public expectations. Wolf et al. [75] traced audit expectation gap to lack of perceived independence and argued that the audit report becomes a document that promotes company's image. Lee et al. [37] attributed the causes to misconception, ignorance by the users, unreasonable public's expectation, weak legislations, and poor quality work by the auditors. The causes also include uncertainty in the nature of auditing [60], the consequence of self-regulation of auditing profession with little or no interference by government [52], the ignorance, misunderstanding, and unreasonable expectations of the users about audit functions [48]. In addition, Shaikh and Talha [64] stated that reasons for audit expectation gap include corporate failures that made the public to lose confidence in the audit process, the retrospection, evaluation of audit performance, and response time lag due to evolutionary development in auditor's role. Ruhnke and Schmidt [58] attribute the causes of audit expectation to exaggeration of the audit expectation gap by the public, inability of the public to accurately assess the performance of the auditors, deficiency in auditors' performance, and auditors are not fully aware of their responsibilities.

\section{Consequences of audit expectation gap}

The audit expectation gap is not without some consequences. Sikka et al. [66] expressed that audit expectation gap has negative impact on the auditing profession. According to them, it undermines the credibility, earnings potential, and reputation associated with audit work. They further stated that in a capitalist economy, the process of wealth creation and political stability depends on the level of confidence people have in the process of accountability. Hence, the audit expectation gap could be injurious to the users of accounting information, regulators, investors and government. The public trust is the 'heartbeat of any profession'. When the trust is lost, the result is credibility problem and erosion of value attached to the profession [11]. The corporate failures are taken to be synonymous with audit failures. This perception by the stakeholders increases the liability risks and the amount of criticisms against the auditors [36, 39].

\section{Reducing the audit expectation gap}

The inherent attributes of the audit expectation gap make its elimination difficult $[29,66]$. The perceived performance of an auditor is dynamic. As such, its measurement is difficult. What is, therefore, possible is to reduce it. The extant literature showed a number of ways on how to reduce it. These include enlarging the auditor's responsibilities regarding fraud, errors, and illegal acts; 
an expanded audit report, audit education, and enhancing the perceived independence of an auditor [40, 44, $63,66]$. In addition, the audit expectation gap can be bridged through mandatory audit rotation, regulating the appointment of auditors and limiting the mix services audit can render [69]. Some studies suggested the use of structured methodologies in the course of an audit assignment. This method would enhance the quality of audit work and improve users' satisfaction, and consequently, reduce the audit expectation gap [31]. However, there is no consensus among the researchers on the use of this method in reducing the audit expectation gap.

\section{Theoretical review}

There are many theories relating to the responsibilities of the auditors and the subject of audit expectation gap, but for the purpose of this study, the role conflict theory was selected and discussed briefly. This is because it is relevant and thus provides theoretical foundation for the empirical study.

\section{The role conflict theory}

The theory provides a theoretical explanation for the existence of audit expectation gap. Rizzo et al. [57] developed the role conflict theory. The theory rests on the premise that the auditor has a responsibility to examine the books of accounts and give credence to the financial statements prepared by the board, and the stakeholders expect the auditor to undertake this assignment faithfully [32]. According to the theory, the auditor assumes the status of a professional person in a social system. As such, the auditor must comply with the role specifications provided to him by the society. Where there is a breach, compliance can be enforced through social action and this may even entail penalties, where it is necessary [17]. Biddle and Thomas [12] described the auditors' role as "the interactions of the normative expectations of the various interest groups in the society. These interest groups are different role senders who may have direct or indirect relationship to the role position". This implies that an auditor is not only responsible to the shareholders, but also to other stakeholders who are the users of accounting information.

From Davidson [17] work, the stakeholders include management, institutional investors, financial analysts, tax authorities, and creditors. All these groups have different expectations, which are in most cases not constant. The expectations of the groups change occasionally because they have to re-define their role specifications and interplay with other societal factors. The multidimensional expectations are the basis for role conflict. Most times an auditor's obligation to first comply with professional rules and regulation governing his work makes him to conflict with his role as a 'watch-dog' to the users of accounts, while at the same time he must protect his own interest. Similarly, when there is a misunderstanding of the nature of auditors' responsibilities, the users' expectation varies and because there are many users of accounting information, their individual expectations may also vary [59]. What determines the magnitude of audit expectation gap is the extent to which auditor is able to provide a trade-off between all the conflicting interests [7].

\section{Empirical review}

There are many prior studies both in developed and emerging countries on the subject of audit expectation gap. These studies $[3,9,11,22,26,41,51,54,61,68]$ mostly used survey questionnaire to identify the inherent attributes of the gap, its effects, and ways of narrowing it. The research studies outcomes largely showed the presence of users misunderstanding as regards auditor's duties and responsibilities. Audit environment, however, influenced the divergent views among the various groups. We have reviewed previous studies, and some of the findings are reported below.

Haniffa and Hudaid [25] studied audit expectation gap by considering the tradition and culture in Saudi Arabia. They collected data, using mailed questionnaire and semi-structured interviews. Descriptive statistics and Mann-Whitney $U$ test were employed for data analysis. The findings showed that the performance gap significantly exists in the area of auditors' responsibilities as statutorily provided for and those reasonable expectations of the public in Saudi Arabia. Salehi et al. [62] examined audit independence and expectation gap in Iran. The questionnaire was distributed to 214 investors and 227 chartered accountants. The data collected were analysed through descriptive statistics and Mann-Whitney $U$ test. The results revealed a significant expectation gap between the investors and auditors on actual level of audit independence in Iran. Lee et al. [37] examined the causes and remedies of audit expectation in Malaysia. The data were gathered from 35 people through semistructured interviews. They noted some complexities in the reasons for audit expectation gap. They attributed the causes to misconception, ignorance by the users, unreasonable public's expectation, weak legislations, and poor quality work by the auditors. Humphrey et al. [28] investigated the audit expectation gap in the UK. They used series of unstructured interviews to obtain data from the management, auditors, investors, regulators, and other undefined respondents. Their results showed that auditors' and financial statements users' perceptions were different in respect of the nature and conduct of an audit. They also confirmed that the concept of accrual reporting 
in accounting contributes to the problem of audit expectation gap. Porter [54] investigated audit expectation gap in New Zealand and observed significant difference in the belief statements of the auditors and audit beneficiaries in relation to the auditors' duties. She noted several differences in attitude. For instance, the audit beneficiaries were of the view that auditors should act as a watchdog to the public, but the auditors did not agree with this position. Salehi [61] investigated audit expectation gap in Iran and used a new approach to measure the gap. He adopted Porter [54] model in measuring the audit expectation gap, and the results confirmed the existence of audit expectation gap in Iran. Farasangi and Nohongdari [20] reviewed the relationship between audit expectation gap from attitude of accreditation of independent auditors and non-payment of granted facilities in Iran. Their results showed a high positive relationship between expectation gap from attitude of accreditation of independent auditors and non-payment of granted facilities. Alawi et al. [6] examined the determinants of audit expectation gap in the Kingdom of Bahrain and concluded that the skills of auditors, efforts of the auditors, the knowledge of the public on audit function, and users' needs from auditors have significant impact on audit expectation gap in Bahrain.

Monroe and Woodliff [44] examined the influence of education on respondents' beliefs concerning information in the audit reports. The study administered questionnaire to the undergraduate students. The outcome revealed an existence of expectation gap and that education had a great influence on the students' beliefs. They also discovered that the use of long-form of auditors' report would significantly affect beliefs and consequently reduce the gap, but new contrasts in beliefs may emerge. Fulop et al. [22] also examined audit education role in reducing the expectation gap. Their findings indicated that audit education has a significant impact in constraining the 'audit reasonableness expectation gap'. Schelluch [63] in his study of long audit report and audit expectation gap observed the persistence of audit expectation gap after the long-form audit report was introduced in Australia. However, perception gaps between auditors and users were narrowed down in some areas, especially in the way the expanded report was worded, although the users still believe strongly that auditors should be responsible for preventing fraud and also expressed concerns on whether the financial information can easily be verified and used consistently. Best et al. [11] investigated the impact of long-form audit report on the audit expectation gap in Singapore. They adopted Schelluch [63] research design and found a moderate audit expectation gap in Singapore, which showed an improvement over the use of short-form audit report. Mansur and Tangi
[41] in their work on how to bridge the audit expectation gap concluded that it could be bridged through educating the users of financial statements and more effective communication between the auditors and the users. Taslima and Fengju [69] used existing literature to review the stakeholders' trust towards the role of auditors and concluded that auditing profession must remove the toga of self-regulation and address the reality of audit expectation gap before this phenomenon would completely erode the trust of the stakeholders.

Adeyemi and Uadiale [3] studied audit expectation gap in Nigeria. They used survey research method and structured questionnaire in collecting data. Using purposive sampling technique, they sampled two hundred (200) respondents. For the analysis of data, descriptive and inferential statistics were used. The testing of the hypotheses was done using analysis of variance (ANOVA). It was revealed in the findings that audit expectation gap existed in Nigeria, and there was significant difference in the beliefs of the groups regarding the responsibilities of auditors. Oseni and Ehimi [50] investigated the nature and degree of audit expectation gap in Nigeria. The data were obtained through questionnaire, and 160 respondents were sampled. They used Chi-square for data analysis, and their results showed that there was an outstanding contrast in the auditor's duties for preventing and detecting fraud. Regarding the difference in belief of auditor's report, Tanko [68] confirmed a wide audit expectation gap on the quality of audit report in the public sector in Nigeria, while Adeyemi and Uadiale [3] observed wide expectation gap on decision usefulness of audit report in the private sector. Onulaka [51] examined the effect of audit expectation gap in the Nigerian capital market and confirmed the wide gap in the areas of auditor's responsibility for fraud detection and prevention. Appolos et al. [9] studied new auditors' reporting standards and its impact on the audit expectation gap. Using desk research method, they concluded that the new auditors' reporting standards would no doubt narrow the gap regarding performance and communication, including liabilities gap.

Considering the issues reviewed, the study hypotheses are stated as follows:

$\mathbf{H}_{\mathbf{0}} \mathbf{1}$ The opinion of the users with respect to the responsibility of the auditors for the audited financial statements is not different from the auditors' opinion.

$\mathbf{H}_{0} 2$ The opinion of the users regarding the reliability of audited financial statements is not different from the auditors' opinion. 
$\mathbf{H}_{0} 3$ The opinion of the users on the decision usefulness of the audited financial statements is not different from the auditors' opinion.

\section{Methods and material}

This study applied the descriptive design and collected data mainly from the primary source. The data were acquired using semantic differential questionnaire, which was adopted from Schelluch [63] and Best et al. [11] to measure the opinions of the respondents regarding the duties and responsibilities of auditors. This is to aid in the provision of an authentic assessment of audit expectation gap in Nigeria and also grant basis for comparison with other prior studies.

\section{Sampling techniques}

The geographical study area for the research is Lagos, and it was chosen because it is the commercial centre of Nigeria. The Nigerian Stock Market and head offices of most of the multi-national companies and banks are also resident in Lagos. The study consists of two (2) sets of population. The first set is users of the financial statements in Nigeria which include, bankers, investors, stockbrokers, and financial analysts, and the second set is the accountants in practice (auditors) in Nigeria. We adopted purposive sampling technique to determine our samples for the two sets of population. The sampling technique enables the researchers to use their skills, prior knowledge, and experience to select appropriate respondents [49]. The major attribute of this technique is that it ensures that data are collected from respondents, who in most cases are difficult to locate, but are crucial to the accomplishment of the study [2]. Consequently, we surveyed 430 respondents in Lagos. The questionnaire was distributed to 300 users and 130 auditors, respectively.

\section{Method of data analysis}

Since the data are nonparametric, the study employed Mann-Whitney $U$ test as a means of analysing the collected data. It is an analogous of $t$ test for two independent samples. The test statistic measures the difference between the ranked observations of two samples [33], hence preferred in this study to ascertain the significance difference among the respondent groups.

We present below the Mann-Whitney $U$ test formula [33] used in the study, and the data are processed, using SPSS Statistics:

$$
U=n_{1} n_{2}+\frac{n_{2}\left(n_{2}+1\right)}{2}-\sum_{i=n_{1}+1}^{n_{2}} R_{i}
$$

where $U=$ Mann-Whitney $U$ test, $n_{1}=$ sample size one, $n_{2}=$ sample size two, $R_{i}=$ rank of the sample size.
Table 1 Respondents response. Source: Survey Data Analysis (2019)

\begin{tabular}{llll}
\hline Group & Survey sent-out & Survey Recd. & $\%$ \\
\hline Users & 300 & 200 & 66.67 \\
Auditors & 130 & 92 & 70.76 \\
Total & 430 & 292 & 67.91 \\
\hline
\end{tabular}

Table 2 Respondents occupation. Source: Survey Data Analysis (2019)

\begin{tabular}{lccc}
\hline Respondents & $\begin{array}{l}\text { Survey } \\
\text { received }\end{array}$ & \% & Cumulative (\%) \\
\hline Financial analysts & 65 & 22.27 & 22.27 \\
Bankers & 46 & 15.75 & 38.02 \\
Stockbrokers & 52 & 17.81 & 55.83 \\
Investors & 37 & 12.67 & 68.50 \\
Auditors & 92 & 31.50 & 100.00 \\
Total & 292 & 100.00 & \\
\hline
\end{tabular}

\section{Results and discussion}

In this section, the results of the primary data analysis are presented and conclusions drawn therefrom.

\section{Respondents response rate}

For this study, 430 copies of questionnaire were sent out to the two groups in our survey. We distributed 300 copies to the users' group and 130 copies to the auditors' group. Provided in Table 1 is the rate of response and other demographic information.

The observation from Table 1 shows a total response rate of $67.90 \%$. This is not only encouraging, but also acceptable for a research of this nature. Breaking this down further shows that $66.67 \%$ and $70.67 \%$ are the response rates for the users group and auditors group, respectively.

\section{Respondents occupation}

Table 2 reveals that $87.33 \%$ of the respondents are engaged in accounting-related occupation. Their professional knowledge and exposure make them most suitable for the survey, and this gives credibility to the study.

\section{Results of statistical tests}

Table 3 shows the results of responsibility statement test, using Mann-Whitney $U$ test. They reveal a high significant difference between the users and the auditors regarding auditors' role in detecting of errors and fraud, maintaining good internal control system, preventing of errors and fraud, keeping the proper records of books of accounts, preparing the financial statements 
and reporting the future prospects. This is confirmed by $p<0.05$. The two groups strongly believe that the auditor should be objective and not biased in the discharge of his responsibilities. However, there is a significant difference as shown in the $p$ value of 0.002 . In the case of professional judgement, the $p$ value of 0.005 is observed and this is lower than 0.05 . There is an equally strong significant difference in the perception of the users and the auditors in the use of professional judgement in choosing audit procedures.

Table 4 shows details of the results of reliability statement statistical test. From the table, the $p$ value for the clarity in the way the work done by the auditors is communicated is 0.238 , which is greater than 0.05 . Hence, no significant difference exists between the two groups, whereas significant difference for the two groups is high regarding the extent of clarity in the expression of audit assurance given by the auditors and the company being free from fraud as confirmed by the $p$ values of 0.000 and
0.002 , respectively, each being less than 0.05 at $5 \%$ significance level. In the case of fairness and no material misstatement in the financial statements factors, a moderate significant difference is observed between both the users and the auditors. This is because their $p$ values of 0.019 and 0.022 , respectively, are less than 0.05 .

Table 5 shows the results of decision usefulness statement statistical test, using Mann-Whitney $U$ test. The results indicate a high significant difference in the views of the users group and the auditors group on whether an unqualified audit report is a proof that the company is well run, as evidenced by the $p$ value of 0.000 which is less than 0.05 . The $p$ values for usefulness of audited financial statements in assessing performance and making decisions are 0.089 and 0.067 , respectively. Thus, we can draw an inference that no major difference exists between the views of users group and auditors group on the two decision usefulness factors because their $p$ values are far above 0.05 .

Table 3 Responsibility statement statistics test. Source: Survey Data Analysis (2019)

\begin{tabular}{|c|c|c|c|c|c|c|c|c|}
\hline Statistics test & $\begin{array}{l}\text { Detecting } \\
\text { errors } \\
\text { and fraud }\end{array}$ & $\begin{array}{l}\text { Preventing } \\
\text { errors } \\
\text { and fraud }\end{array}$ & $\begin{array}{l}\text { Good internal } \\
\text { control } \\
\text { system }\end{array}$ & $\begin{array}{l}\text { Maintain } \\
\text { proper } \\
\text { books }\end{array}$ & $\begin{array}{l}\text { Preparing } \\
\text { financial } \\
\text { statements }\end{array}$ & $\begin{array}{l}\text { Objectivity } \\
\text { of the auditor }\end{array}$ & $\begin{array}{l}\text { The use } \\
\text { of judgement } \\
\text { in the selection } \\
\text { of audit } \\
\text { procedure }\end{array}$ & $\begin{array}{l}\text { Reporting } \\
\text { of future } \\
\text { prospect }\end{array}$ \\
\hline Mann-Witney $U$ & 3659.00 & 4529.50 & 4219.00 & 5812.50 & 5161.50 & 7219.50 & 7444.00 & 6408.00 \\
\hline Wilcoxon W & $24,365.00$ & $25,235.50$ & $24,925.00$ & $26,518.50$ & $25,867.50$ & $11,405.50$ & $11,630.00$ & $27,114.50$ \\
\hline Z & -8.452 & -7.120 & -7.565 & -5.228 & -6.220 & -3.148 & -2.813 & -4.289 \\
\hline $\begin{array}{l}\text { Asymp. Sig. } \\
\text { (2-tailed) }\end{array}$ & 0.000 & 0.000 & 0.000 & 0.000 & 0.000 & 0.002 & 0.005 & 0.000 \\
\hline
\end{tabular}

Table 4 Reliability statement statistics test. Source: Survey Data Analysis (2019)

\begin{tabular}{lcccc}
\hline Statistics test & $\begin{array}{l}\text { Fairness } \\
\text { of the financial } \\
\text { statements }\end{array}$ & $\begin{array}{l}\text { Clarity } \\
\text { in the expression } \\
\text { of audit assurance }\end{array}$ & $\begin{array}{l}\text { The firm being } \\
\text { free from fraud }\end{array}$ & $\begin{array}{l}\text { Clear communication } \\
\text { of the amount of audit } \\
\text { done }\end{array}$ \\
\hline Mann-Witney $U$ & 7759.50 & 5957.50 & $\begin{array}{l}\text { The financial statements } \\
\text { contain no material } \\
\text { misstatement }\end{array}$ \\
Wilcoxon W & $11,945.50$ & $26,663.50$ & $27,901.50$ & $29,101.50$ \\
Z & -2.347 & -5.086 & -3.088 & -1.179 \\
Asymp. Sig. (2-tailed) & 0.019 & 0.000 & 0.002 & 0.238 \\
\hline
\end{tabular}

Table 5 Decision usefulness statement statistics test. Source: Survey Data Analysis (2019)

\begin{tabular}{lcc}
\hline Statistics test & $\begin{array}{l}\text { Usefulness of audited financial statements } \\
\text { in assessing performance of a firm }\end{array}$ & $\begin{array}{c}\text { Usefulness of audited financial } \\
\text { statements in making decisions }\end{array}$ \\
\hline Mann-Witney $U$ & 8189.50 & $\begin{array}{l}\text { A clean audit report } \\
\text { showing that a firm } \\
\text { is doing well }\end{array}$ \\
Wilcoxon W & $28,895.00$ & $28,8107.50$ \\
$Z$ & -1.700 & -1.832 \\
Asymp. Sig. (2-tailed) & 0.089 & 0.067 \\
\hline
\end{tabular}


Table 6 reveals that $p$ values for the three hypotheses are $0.000,0.004$ and 0.000 , respectively, which means that all three hypotheses are less than 0.05 . Consequently, the null hypothesis $\left(\mathrm{H}_{0}\right)$ is rejected at $5 \%$ significance level. By this outcome, we conclude that wide significant differences exist in the opinions of the two groups, users, and auditors in relation to responsibility, reliability, and decision usefulness statements.

Table 7 presents the outcome of the normality test. From the table, the $p$ values for the users group and auditors group are 0.663 and 0.748 , respectively. The $p$ value is higher than 0.05 for each group (users and auditors); this implies that perceptions of the two groups are normally distributed.

\section{Discussion}

The primary objective of the study was to empirically investigate the extent and nature of audit expectation gap in Nigeria. The hypotheses results confirmed the non-suitability of the null hypotheses for this study and hence, their rejection. We therefore conclude that there is a gap between the perceptions of the users and the auditors with reference to reliability, decision usefulness statements, and responsibility. From the result, the audit expectation gap was quite high in the area of the auditor's responsibilities, especially with regard to the prevention and detection of errors and frauds, maintaining of the proper books and the preparation of financial statements. These findings are consistent with the results of Best et al. [11], Adeyemi and Uadiale [3, 48], except that Best et al. [11] did not find audit expectation gap in the preparation of financial statements. To a lesser extent, there was a significant difference between the two respondent groups on the extent of clarity of expression in assurances given by the auditors and clean report as a sign that the entity being well managed. Best et al. [11], on the contrary, found no significant difference on the two reliability and decision usefulness statements.

\section{Conclusion, contribution, and recommendation}

This research confirmed the existence of audit expectation gap in Nigeria. The impact of the new auditor's report was yet to be seen. This was partly due to the noncompliance by many of the audit firms and the nature of the audit expectation in the country. The audit expectation gap was more pronounced in the area of auditor's duties and responsibilities. While the users believed that the auditor's duties and responsibilities as defined by the Companies and Allied Matters Act of 2004 should be expanded to cover the prevention and the detection of errors and fraud, the auditors were of the view that such an amendment in the legislation would negate the whole essence of audit. From the outcome of this study, the audit expectation gap primarily arose from the unreasonable expectation of the users due to their lack of understanding on the roles of auditors. This is consistent with the role conflict theory, which states that conflict in the perception of the role of auditors is what is called "audit expectation gap".

The auditors' role is described as "the interactions of the normative expectations of the various interest groups in the society. These interest groups are different role senders who may have direct or indirect relationship to the role position" [12]. This implies that an auditor is not only responsible to the shareholders, but also to other stakeholders who are the users of accounting

Table 6 Testing of hypothesis. Source: Survey Data Analysis (2019)

\begin{tabular}{|c|c|c|c|c|c|c|}
\hline Statement & Respondents response & Mean rank & Sum of rank & Mann-Whitney $U$ & $p$ value & Decision \\
\hline \multirow[t]{2}{*}{ Responsibility } & \multirow[t]{2}{*}{ Users auditors } & 118.85 & $24,306.00$ & \multirow[t]{2}{*}{3601.00} & \multirow[t]{2}{*}{0.000} & \multirow[t]{2}{*}{ Reject } \\
\hline & & 208.31 & $19,055.00$ & & & \\
\hline \multirow[t]{2}{*}{ Reliability } & \multirow[t]{2}{*}{ Users auditors } & 137.06 & $28,002.50$ & \multirow[t]{2}{*}{7298.50} & \multirow[t]{2}{*}{0.004} & \multirow[t]{2}{*}{ Reject } \\
\hline & & 167.64 & $15,358.50$ & & & \\
\hline \multirow[t]{2}{*}{ Decision usefulness } & \multirow[t]{2}{*}{ Users auditors } & 128.57 & $26,271.00$ & \multirow[t]{2}{*}{5564} & \multirow[t]{2}{*}{0.000} & \multirow[t]{2}{*}{ Reject } \\
\hline & & 186.77 & $17,091.00$ & & & \\
\hline
\end{tabular}

Table 7 Test of the distribution normality. Source: Survey Data Analysis (2019)

\begin{tabular}{|c|c|c|c|c|c|c|c|}
\hline \multirow[t]{2}{*}{ Statement } & \multirow[t]{2}{*}{ Group } & \multicolumn{3}{|c|}{ Kolmogorov-Smirnov } & \multicolumn{3}{|c|}{ Shapiro-Wilk } \\
\hline & & Statistic & $d f$ & Sig. & Statistic & $d f$ & Sig \\
\hline \multirow[t]{2}{*}{ The auditor has a responsibility for detecting all errors and fraud } & Users auditors & 0.274 & 200 & 0.663 & 0.824 & 200 & 0.633 \\
\hline & & 0.369 & 92 & 0.748 & 0.642 & 92 & 0.570 \\
\hline
\end{tabular}


information. Hence, the auditors face a multi-task and multi-expectation assignment that is difficult to fulfil. The role conflict indicates that statutory objective of audit is not responsive to societal expectations. In Nigeria, the audit expectation gap is due to the changes in the business environment. Consequently, the auditors are constantly under the threat of a credibility and liability crisis from the increased litigation against and criticism of their work [37]. However, the audit expectation gap poses a very serious threat to the auditing profession and auditors cannot continue to maintain a legalistic posture, while the public are dissatisfied with their services. More so, the evolution in auditing profession has always been based on the changing demands in the society. For audit to sustain its relevance, the profession must improve on the speed of response to the demands of the society.

Based on the empirical findings of this study, these recommendations are provided:

1. The auditors should improve the communication level in order to address the users' misconception of audit services and function. The introduction of the new auditor's report by the International Auditing and Assurance Standards Board (IAASB) in 2016 was a response to the recommendations of the prior studies on the expanded audit report, but the local regulatory bodies in the country must ensure its compliance and enforcement to the fullest in order to produce the desired results.

2. The Companies and Allied Matters Act (CAMA) [15] should be reviewed with a view to expanding the existing duties and responsibilities of the auditors particularly, accommodating the demand of the public in terms of the prevention and the detection of errors and fraud. If this must be done, more powers should be given to the auditors to enable them report any serious misconduct of the directors to the appropriate regulatory authority. This is whistleblowing, which can serve as a safety valve against fraud, irregularities, and excessive risk taking. The July 2016 pronouncements on responding to non-compliance with laws and regulations by International Ethics Standards Board for Accountants (IESBA) are steps in the right direction.

3. The rotation of external auditors provided for in the Nigerian Code of Corporate Governance (2018) is principle-based, and we suggest that it should be made compulsory for all companies by including this provision in Companies and Allied Matters Act with stiff penalty for non-compliance.

4. An audit firm should not be allowed to carry out both audit and non-audit professional services in a client organization. This is to preserve the auditors' independence and avoid conflict of interest that normally attend the rendering of the two professional services.

5. On a longer term, the regulatory agencies with the support of audit firms should facilitate the launching of a new business-reporting model geared towards releasing more non-financial information to the public and with clear description of the role of independent audit.

\begin{abstract}
Abbreviations
AAA: American Accounting Association; ANOVA: Analysis of variance; CAAT : Computer-assisted audit techniques; CAMA: Companies and Allied Matters Act; IESBA: International Ethics Standards Board for Accountants; IAASB: International Auditing and Assurance Standards Board.
\end{abstract}

\section{Acknowledgements}

Not applicable.

\section{Authors' contributions}

PO worked on the abstract and introductory section, while OE contributed in the area of literature review and research methods. OA analysed the data for the study and discussed the findings. MU performed the general editing of the paper and the referencing section. All authors read and approved the final manuscript

\section{Funding}

There is/are no funding available for this research from any institution.

\section{Availability of data and materials}

The data sets used and/or analysed during the current study are available from the corresponding author on reasonable request.

\section{Consent for publication}

The authors give their consent for this article to be published.

\section{Competing interests}

The authors declare that they have no competing financial or personal interests from other parties.

\section{Author details}

${ }^{1}$ Covenant University, Ota, Nigeria. ${ }^{2}$ Kogi State University, Anyigba, Nigeria.

Received: 19 July 2019 Accepted: 26 February 2020

Published: 23 April 2020

References

1. ACCA (2019) Closing expectation gap in audit. www.accaglobal.com/ content/dam/ACCA_Global/professional-insight/expectation-gap. Accessed 27 Dec 2019

2. Adefila J (2008) Research methodology in behavioral sciences. Apani Publications in Association with Loud Books (Publishers), Ibadan

3. Adeyemi S, Uadiale $O$ (2011) An empirical investigation of audit expectation gap in Nigeria. Afr J Bus Manage 5(19):7964-7971

4. Agrawal K, Chatterjee C (2015) Earnings management and financial distress: evidence from India. Glob Bus Rev 16(5):140-154

5. Akinbuli S (2010) The effect of expectation gap on the work of auditors, the profession and users of financial information. Niger Account 2:37-47

6. Alawi S, Wadi R, Kukreja G (2018) Determinants of expectation gap: an empirical study from the Kingdom of Bahrain. Account Finance Res 7(3):55-66 
7. Alleyne P, Devonish D (2006) Perceptions of auditor's independence in Barbados. Manag Audit J 21(6):621-635

8. Alleyne P, Howard M (2005) An exploratory study of auditors' responsibilities for fraud detection in Barbados. Manag Audit J 20(3):284-303

9. Appolos N, Onuoha L, Aguguom A (2016) The new auditors' reporting standards and the audit expectation gap. Int J Adv Acad Res Soc Manag Sci 2(11):118-133

10. Arens A, Peter J, Gregory E, James K (1997) Auditing in Australia, 4th edn. Prentice Hall, Melbourne

11. Best P, Buckby S, Tan C (2001) Evidence of the audit expectation gap in Singapore. Manag Audit J 16(3):134-144

12. Biddle BJ, Thomas EJ (1979) Role theory: concept and research. Robert E. Krieger Publishing $\mathrm{Co}$, Huntington

13. Boterenbrod R (2017) The audit expectation gap between companies and their auditors: an exploratory study. Glob Bus Rev 18(5):1 124-1133

14. Commission Cohen (1978) Report of the commission on auditors' responsibilities: conclusions and recommendations. American Institute of Certified Public Accountants, New York

15. Company \& Allied Matters Act (2004) C20, Law of the Federal Republic of Nigeria

16. Cramer J, Sorter G (1974) Objectives of financial statements. Selected papers, vol 2. AICPA, New York

17. Davidson L (1975) The role and responsibilities of the auditor: perspective, expectations and analysis. Unpublished background paper for the Commission on auditors' responsibilities

18. Ekpenyong DB (1985) Firm's propensity to switch auditors: an exploratory study of some Nigerian firms. Niger Manag Rev 9(1):67-78

19. Erin O, Ogundele I, Ogundele O (2016) Whistleblowing policy and quality of financial reporting in the Nigerian Banking Sector. A paper presented at the third International Conference on African Development Issues, May, 15-17

20. Farasangi S, Nohongdari A (2017) Investigating the relationship between expectation gap from attitude of accreditation of audit report by credit experts and non-payment of granted facilities in the branches of Keshavarzi bank in Iran. Int J Econ Financ Issues 7(4):199-206

21. Flint D (1988) Philosophy and principles of auditing: an introduction. Macmillan, London

22. Fulop M, Tiron-Tudor A, Silviu G (2019) Audit education role in decreasing the expectation gap. J Educ Bus 94(5):306-313

23. Glaulier M, Underdown B (2001) Accounting theory and practice. ELBS, 7th edn. FT-Prentice Hall, London

24. Godsell D (1992) Legal liability and the audit expectation gap. Singap Account 8:25-28

25. Haniffa R, Hudaib M (2007) Locating audit expectation gap within a cultural context: the case of Saudi Arabia. J Int Account Audit Tax 16(2):179-206

26. Hojskov L (1998) The expectation gap between users and auditors' materiality judgements in Denmark. A paper presented at the second Asian Pacific interdisciplinary research in accounting conference, August, 4-6, Japan

27. Houghton K, Jubb C, Kend M (2011) Materiality in the contest of audit: the real expectation gap. Manag Audit J 26(6):482-500

28. Humphrey C, Moizer P, Turley S (1992) The audit expectation gap in the United Kingdom. The Institute of Chartered Accountants in England and Wales, London

29. Jedidi I, Richard C (2009) The social construction of audit expectation gap: the market of excuses. La place de la dimension europeenne dans la Comptabillite controle Audit Strasbourg, Strasbourg

30. King M, De Beer L (2018) The auditors Quo Vadis?, 1st edn. Routledge, London

31. Koh J, Woo E (1998) The expectation gap in auditing. Manag Audit J 13(3):147-154

32. Koo C, Sim H (1999) On the role conflict of auditors in Korea. Account Audit Account J 12(2):206-219

33. Kothari C, Garg G (2014) Research methodology: methods and techniques. New Age International (P) Limited, Publishers, New Delhi

34. Lee T (1970) The nature of auditing and its objectives. Accountancy 81:292-296

35. Lee T, Gloeck J, Palaniappan A (2007) The audit expectation gap: an empirical study in Malaysia. South Afr J Account Audit Res 7(1):1-15
36. Lee T, Azham A, Kandasamy S (2008) Towards reducing the audit expectation gap: possible mission? Account Today 3:18-22

37. Lee TH, Alli AM, Gloeck J (2009) The audit expectation gap in Malaysia: an investigation into its causes and remedies. S Afr J Account Audit Res 9:57-88

38. Liggio CD (1974) The expectation gap: the accountants' waterloo. J Contemp Bus 3(3):23-35

39. Maccarrone $E$ (1993) Using the expectation gap to close the legal gap. CPA J 63:10-18

40. Commission Macdonald (1988) Report on the commission to study the public's expectation of audits. Canadian Institute of Chartered Accountants, Toronto

41. Mansur H, Tangi A (2018) How to bridge the audit gap? J Soc Sci 7(2):61-63. https://doi.org/10.25255/jss.2018.7.2.61.73

42. Mautz R, Sharaf H (1986) The philosophy of auditing, 13th edn. American Accounting Association, Sarasota

43. Messier W, Martinov-Bennie N, Eilifsen A (2005) A review and integration of empirical research on materiality: two decades later. Audit J Pract Theory 24(2):153-187

44. Monroe GS, Woodliff DR (1994) An empirical investigation of the audit expectation gap: Australian evidence. Account Finance 34(1):47-74

45. Ojo M (2006) Eliminating the audit expectation gap: Myth or reality? Munich Personal RePeEc Archives. http://mpra.ub.uni.muenchen.de/232/ mpra_paper. Accessed 30 Oct 2017

46. Okoye L, Erin O, Ado A, Areghan I (2017) Corporate governance and financial sustainability of microfinance institutions in Nigeria. In: Proceedings of the 29th international business information management association conference, IBIMA 2016: sustainable economic growth, education excellence and innovation management through vision 2020

47. Olojede P (2009) Bridging the audit expectation gap: the Nigerian experience. Unpublished M.Sc. dissertation, Leeds Metropolitan University, UK

48. Olowoookere J, Soyemi K (2013) Evidence of audit expectation gap in Nigeria. J Emerg Trends Econ Manag Sci 4(6):539-546

49. Ogunbameru O (2003) Research methods in social sciences, 2nd edn. D-Net Communications E-Books Press, Oslo

50. Oseni A, Ehimi C (2010) Existence and nature of audit expectation gap: Nigerian perspective. Asian Econ Financ Rev 2(8):1051-1063

51. Onulaka P (2014) Effect of audit expectation gap in Nigerian capital market. Int J Account Financ Report 4(2):294-311

52. Onulaka P, Samy M (2017) Influence of self-regulatory policy of auditing profession on audit expectation gap: qualitative methodological approach. Mediterr J Soc Sci 8(1):96-104

53. Owolabi MB (2007) The unethical practices of accountants and auditors, and the compromising stance of professional bodies in the corporate world: evidence from corporate Nigeria. Account Forum 31(3):34-49

54. Porter B (1993) An empirical study of audit expectation - performance gap. Account Bus Res 24:49-68

55. Porter B, Simon J, Hatherly D (2005) Principles of auditing. Wiley, New York

56. Razaee Z (2004) Restoring public trust in the accounting profession by developing anti-fraud education, programmes and auditing. Manag Audit J 19(1):134-148

57. Rizzo J, House R, Lirtzman S (1970) Role conflict and ambiguity in complex organizations. Adm Sci Q 15:150-163

58. Ruhnke K, Schmidt M (2014) The audit expectation: existence, causes and the impact of changes. Account Bus Res 44(5):572-580

59. Saha A, Baruah D (2008) Audit expectation gap in India: an empirical survey. ICFAl J Audit Pract 5(2):68-83

60. Salehi M (2011) Audit expectation gap: concepts, nature and trace. Afr J Bus Manage 5(21):8376-8392

61. Salehi M (2016) Quantifying audit expectation gap: a new approach to measuring expectation. Zagreb Int Rev Econ Bus 19(1):25-44

62. Salehi M, Masoury A, Azary Z (2009) Independence and audit expectation gap: empirical evidence from Iran. Int J Econ Finance 1(1):165-174

63. Schelluch P (1996) Long-form audit report messages: further implications for audit expectation gap. Account Res J 9:48-50

64. Shaikh J, Talha M (2003) Credibility and expectation gap in the reporting on uncertainties. Manag Audit J 18(6):517-529

65. Sikka P, Puxty T, Willmott H, Cooper C (1992) Eliminating the expectation gap, Research Report No. 28. ACCA, London 
66. Sikka P, Puxty A, Willmott H, Cooper C (1998) The impossibility of eliminating the expectation gap: some theory and evidence. Crit Persp Account 9(3):299-330

67. Spiceland J, Sepe J, Tomassini L (2001) Intermediate accounting. McGrawHill, New York

68. Tanko M (2011) An empirical analysis of audit expectation gap in Nigeria. Munich Personal RePEC Archive, MPRA Paper No. 49661, pp 1-18. http:// mpra.ub.uni-muenchen.de/49661. Accessed 15 Sept. 2018

69. Taslima A, Fengju X (2019) Stakeholders' trust towards the role of auditors: a synopsis of the audit expectation gap. J Manag Sci 6(1):43-49

70. The Corporate Report (1975) A discussion paper. The Accounting Standards Steering, London. https://www.icaew.com/library/subject...corpo rate-reporting/Thecorporate-report. Accessed 05 Sept. 2018

71. Tricker R (1982) Corporate accountability and the role of audit function. In: Bromwich M, Hopwood AG, Shaw J (eds) Auditing research issues and opportunities. Pitman, London
72. Tweedie D (1987) Challenges facing the auditor professional fouls and the expectation gap. Deloitte, Haskins and Sells Lecture, University College, Cardiff

73. Uwuigbe O, Olorunshe O, Uwuigbe U, Ozordi E, Asiriuwa O, Asaolu T, Erin O (2019) Corporate governance and financial statement fraud among listed firms in Nigeria. In: IOP conference series: earth and environmental science, vol 331, p 012055

74. Williams RG (1974) Principles and practice of auditing, 17th edn. Donnington Press, London

75. Wolf F, Tackett J, Claypool G (1999) Audit disaster future: antidote for audit expectation gap. Manag Audit J 14(9):468-478

\section{Publisher's Note}

Springer Nature remains neutral with regard to jurisdictional claims in published maps and institutional affiliations.

\section{Submit your manuscript to a SpringerOpen ${ }^{\circ}$ journal and benefit from:}

- Convenient online submission

- Rigorous peer review

- Open access: articles freely available online

- High visibility within the field

- Retaining the copyright to your article

Submit your next manuscript at $\boldsymbol{\nabla}$ springeropen.com 